\title{
Current Application of Microencapsulation Technology in Bioremediation of Polluted Groundwater
}

\author{
${ }^{1}$ Magister of Medical Laboratory Science Study Program, Universitas Muhammadiyah Semarang, Indonesia \\ ${ }^{2}$ Department of Fisheries and Marine Sciences, Diponegoro University, Indonesia \\ ${ }^{3}$ Department of Fisheries and Marine Sciences, Diponegoro University, Indonesia \\ ${ }^{4}$ Diploma 3 of Medical Laboratory Technology Study Program, Universitas Muhammadiyah Semarang, Indonesia \\ ${ }^{5}$ Diploma 4 of Medical Laboratory Technology Study Program, Universitas Muhammadiyah Semarang, Indonesia \\ ${ }^{5}$ Diploma 3 of Medical Laboratory Technology Study Program, Universitas Muhammadiyah Semarang, Indonesia \\ ${ }^{6}$ Mechanical Engineering Study Program, Universitas Muhammadiyah Semarang, Indonesia \\ ${ }^{7}$ Magister of Medical Laboratory Science Study Program, Universitas Muhammadiyah Semarang, Indonesia
}

Stalis Norma Ethica1*, Akbar Firmansyah², Sakti Imam Muchlissin ${ }^{3}$, Ayu Rahmawati Sulistyaningtyas ${ }^{4}$, Aditya Rahman Ernanto ${ }^{5}$, Ragil Saptaningtyas ${ }^{5}$, RM Bagus Irawan Widyawardhana ${ }^{6}$ and Sri Darmawati ${ }^{7}$

*Corresponding author: Stalis Norma Ethica, Magister of Medical Laboratory Science Study

Program, Universitas Muhammadiyah Semarang, Indonesia.

Received Date: February 10, 2020

Published Date: February 28, 2020

\section{Abstract}

Major challenges in global groundwater supply mainly Come from population growth and climate change requiring innovative water technologies to keep steady supply of drinking water and decrease water pollution worldwide. In particular, agricultural activities impact groundwater pollution. Against this background, the adaptation of highly advanced bioremediation supported by microencapsulation technology to traditional process engineering offers new opportunities in technological developments for advanced groundwater and wastewater technology processes. In this study, benefits of microencapsulation technology for in situ bioremediation of polluted groundwater applications, particularly in bio-augmentation and bio-stimulation, are presented. In addition, an overview of recent advances in microencapsulation technology for contaminated groundwater treatment processes is provided, including the use of various micro-carrier materials are also summarized.

Keywords: Microencapsulation; Groundwater contamination; Micro-carrier; Bioremediation

\section{Introduction}

The long-term establishment of the global water supply and sustainability is closely related with the world population growth and global climate change. Steadfast growth of the world's population forecasted to be almost multiplied by two from 3.4 to 6.3 billion between 2009 - 2050, is presented by a predicted required growth of $70 \%$ agriculture production by 2050 [1]. Hence, the need for fresh water is dramatically increasing, especially for food production. It is because $70 \%$ of the withdrawals of world's freshwater are already adjudged for agricultural land irrigation. Today each year, 64 billion cubic meters of fresh water are consumed progressively by worlds' population [2].
In developing countries, ground water contamination is a key issue, with high levels of pollutants being reported in various regions. Various contamination control and groundwater treatment technologies methods should be applied to overcome this problem [3]. Groundwater treatment technologies encompass physical, chemical, or biological treatment techniques. They could be divided as ex-situ or in-situ technologies.

Aside of world population growth and global climate change, in particular, agricultural activities have been known to give impact to groundwater pollution. For example, high nitrogen 
fertilizers application rates have been associated with the raise of groundwater pollution [4]. Groundwater has been found as vulnerable to pesticides used in agricultural land [5].

Public concern with polluted soil and groundwater encouraged the development of programs designed to control and remediate this contamination, as well as to prevent further contamination [1]. Bioremediation as an environmentally friendly, socially allowable and economically viable is among the best way to eliminate pollutants from the environment. In bioremediation, microorganisms with beneficial biological activity, including fungi, algae, bacteria, and yeast, could be utilized in their naturally occurring forms [6].

In situ bioremediation involving bio-stimulation and/ or bioaugmentation, being an economical and eco-friendly approach, has come out as the most beneficial soil and water clean-up technique for contaminated sites [7]. Systems involving degrading bacteria have been found helpful in supporting bioremediation option to treat the polluted groundwater [8]. Cells of degrading bacteria have been known as bioremediation agent [9]. Microencapsulation is among important strategy used in bio-augmentation and biostimulation improve the effectiveness of bioremediation processes [10].

Microencapsulation is among quality preservation techniques of vulnerable substances, such as enzymes, living bacterial cells, phytochemicals, and a method for generation of materials with novel precious characteristics. Microencapsulation is defined as a process of packing micron-sized particles in a polymeric shell. Various techniques are now available for the encapsulation of different entities. This mini review provides a literature review of different microencapsulation techniques applied in bioremediation of groundwater worldwide in the last ten years [1].

\section{Discussion}

\section{Bioremediation for polluted groundwater}

With latest advancements, bioremediation offers an environmentally friendly, socially acceptable and economically viable as well as choice option to deplete pollutants from the environment. There are three major ways of bioremediation including the use of microorganisms, plants and enzymes as remediation agent [11].

Bioremediation technology optimizes and exploits the natural role of microorganisms in the transformation and mineralization of these environmental pollutants. The range of contaminated environments may include surface and subsurface soils and surface and groundwater. Bioremediation for contaminated sites including groundwater containing heavy metals and/or organic pollutants usually involves bio-augmentation and/or bio-stimulation [10]. Bioaugmentation could be defined as addition of pre-grown microbial cultures to support the degradation of unwanted substances (contaminants), while bio-stimulation is the injection of nutrients and other supplementary substances to the indigenous microbial population to influence propagation at a stimulated rate [7].

As the concern towards environmental deterioration grows worldwide, new technological achievements become important for all countries. Among the technologies offering great potential of bioremediation is the microencapsulation of active material including living cells or microorganisms [12]. For bioremediation to be effective, microorganisms must enzymatically attack the pollutants and convert them to harmless products [11].

\section{Role of microencapsulation in bioremediation}

Microencapsulation is defined as a process of enclosing or encapsulating micron-sized particles of solids or small drops of liquids or gasses in an inert shell, which in turn protects and isolates them from the external environment [13]. Micro-particles are products obtained by microencapsulation. When the particles have diameter between $3-800 \mathrm{~mm}$, they are regarded as micro-particles, microspheres or microcapsules. Micro-capsules are distinguished from microspheres in terms of morphology and internal structure [14].

Microencapsulation is a technology developed to pack solids, liquids and gases in tiny, sealed capsules isolating and protecting them from harsh environmental factors, such as moisture, light, oxygen, and interaction with other substances. Such microcapsules could gradually release their contents under specific conditions at controlled rates. Those packs are spherical with a micrometer size; yet are highly affected by the structure of micro-carriers and the core components $[15,16]$.

Degradation activities naturally mediated by microorganisms used as bioremediation agent could detoxify pollutants. It is also the goal bioremediation to develop reliable technology, which can accelerate this degradation process, to reduce health risks of the pollutants and to restore the affected site into its natural state. However, even though these organisms have high degradation performance, there are limitations in success including microbial inoculum distribution and handling, suppression by parasites and predators as well as nutrient limitation [17]. These factors highly affect microbial bioremediation agent to survive in the environment. To overcome the issues, possible strategies include improved delivery system of microbial inoculum on microencapsulation technology, which could provide protection through the making of micro-environments and allow controlled release of inoculum to the targeted site [18].

\section{Bio-stimulation supported by microencapsulation}

Bio-stimulation is a commonly used technique for bioremediation involving the addition of rate-limiting nutrients to speed up the biodegradation process. Bio-stimulation often includes the addition of oxygen and nutrients to aid indigenous microorganisms used as bioremediation agent. The nutrients are essential as the basic building blocks of life allowing the microorganisms to produce particular enzymes, which could degrade pollutants [11]. 
A number of studies have reported the use of controlled release of active materials as a way of bio-stimulation and providing the nutrients required or essential for the bioremediation process [12]. In this sense, bio-stimulation could be highly supported by microencapsulation. The use of microencapsulated microorganisms offers a great potential in degrading pollutants through bioremediation. Microencapsulation of living microbial cells in a semi-permeable gel or carrier materials bring more advantages over the free cell bio-augmentation. The microencapsulation could prevent microbial cells from bacteriophage infections and protozoa grazing. It supports both biological and physical stabilities, by decreasing risks such as brief and sudden variations of $\mathrm{pH}$ or temperature; covers from abiotic stresses coming from heavy metals or other toxic compounds [19]. In addition, microencapsulation using carboxymethyl-cellulose as microcarrier could form fine structures for nutrient release, producing bio-stimulation in biodegradation process [12]. Thus, in general, microencapsulation is beneficial in enhancing cell survival and high biomass concentration

\section{Bio-augmentation supported by microencapsulation}

Bioremediation of pollutants or contaminants by utilizing microorganisms is among the most important strategies to eliminate contaminants from groundwater. However, there are limitations of this approach since many contaminants are not efficiently removed [11]. To overcome these limitations, bio-augmentation also includes addition more specific and efficient pollutantbiodegrading microorganisms into a microbial community as a way to support the ability of this microbial community to biodegrade contaminants. In this aspect, microencapsulation of the pollutant- biodegrading microbial cells is relevant to allow steady supply of the bioremediation agent.

To date, the elimination of contaminants by bio-augmentation has been widely investigated in surface water, soil and groundwater [19]. However, although it has been practiced in agriculture and in wastewater treatment for years, bio-augmentation is still experimental. Many factors (e.g. predation, competition or sorption) conspire against it. However, a number of strategies have been explored to make bio-augmentation a beneficial technology in sites lacking significant populations of biodegrading microorganisms. The pollutant degradation rate under optimal local conditions, may increase upon addition of an inoculant to remediate a chemical spill; yet, the most successful examples of bio-augmentation occur in confined systems, such as bioreactors allowing controlled conditions to favor prolonged activity and survival of the exogenous microbial population [20].

\section{Micro-carriers used in groundwater bioremediation applications}

One of the vital steps in micro-coating is choosing the most suitable wall materials/ micro-carriers. Micro-carriers or coating materials usually are film-forming materials opted from various natural and synthetic polymers, or combination of both, depending on the inner component and the overall desired microcapsule characteristics $[15,21]$. Ideally, the wall or sphere material should be an emulsifier, so it could promote enough content release when reconstructed into the product, have a low viscosity due to high concentrations of solids, have good film-forming performance, and have high hygroscopicity.

Table 1: Reported studies related with the application of microencapsulation technology for bioremediation of polluted groundwater in the last decade (2010-2020).

\begin{tabular}{|c|c|c|c|c|}
\hline Pollutant & $\begin{array}{l}\text { Encapsulated Microor- } \\
\text { ganism }\end{array}$ & Micro-Carrier & $\begin{array}{c}\text { Coun- } \\
\text { try }\end{array}$ & Author \\
\hline Atrazine & Pseudomonas sp. & $\begin{array}{l}\text { Polyethylene oxide; polycaprolactone, polyethylene } \\
\text { glycol }\end{array}$ & Israel & $\begin{array}{l}\text { Klein et al., } \\
2012\end{array}$ \\
\hline Xylene & Streptomyces sp. & Sodium alginate & Algeria & $\begin{array}{l}\text { Chiki et al., } \\
2015\end{array}$ \\
\hline Hydrocarbon & Bacillus subtilis & Chitosan & Brazil & $\begin{array}{l}\text { Dellagnezze } \\
\text { et al., } 2016\end{array}$ \\
\hline $\operatorname{Cr}(\mathrm{III})$ & Lysinibacillus fusiformis & Arabic gum and sorbitol & China & $\begin{array}{l}\text { Huang et al., } \\
\quad 2016\end{array}$ \\
\hline Dichlobenil herbicide & Aminobacter sp. & Trehalose & $\begin{array}{l}\text { Den- } \\
\text { mark }\end{array}$ & $\begin{array}{c}\text { Schultz } \\
\text { Jensen et al., } \\
2016\end{array}$ \\
\hline Trichloroethylene (TCE) & $\begin{array}{l}\text { Pseudomonas putida; Dehalo- } \\
\text { coccoides sp. }\end{array}$ & Zero-valent iron (ZVI) & USA & $\begin{array}{l}\text { Shanbhogue } \\
\text { et al., } 2017\end{array}$ \\
\hline \multirow{3}{*}{ Phenol } & Pseudomonas sp., & Gellan gum & $\begin{array}{l}\text { Malay- } \\
\text { sia }\end{array}$ & Aisami, 2017 \\
\hline & Alcaligenes sp., & & & \\
\hline & Serratia sp. & & & \\
\hline $\mathrm{Cr}(\mathrm{VI})$ & Morganella morganii & Polystyrene; polysulfone & Turkey & $\begin{array}{l}\text { Sarioglu, et } \\
\text { al., } 2017\end{array}$ \\
\hline $\begin{array}{l}\text { 1,4-dioxane; chlorinated aliphatic } \\
\text { hydrocarbons }\end{array}$ & Rhodococcus rhodochrous & Alginate; gellan gum & USA & $\begin{array}{l}\text { Rasmussen } \\
2018\end{array}$ \\
\hline
\end{tabular}




\begin{tabular}{|c|c|c|c|c|}
\hline \multirow{2}{*}{ Acetochlor herbicides } & Sphingomonas sp. & No micro-carrier, dried cells & China & $\begin{array}{c}\text { Wang et al., } \\
2018\end{array}$ \\
\hline \multirow{2}{*}{ Trichloroethylene (TCE) } & Lactobacillus casei, & Polyvinyl alcohol (PVA); sodium alginate (SA) & USA & $\begin{array}{c}\text { Nutter et al., } \\
2019\end{array}$ \\
\cline { 2 - 5 } & L.acidophilus & & & \\
\hline Trichloroethene & Clostridium butyricum & Silica gel & Taiwan & Lo et al., 2020 \\
\hline Carbazole & Thalasosspira profundimaris & Gellan gum & $\begin{array}{c}\text { Malay- } \\
\text { sia }\end{array}$ & $\begin{array}{c}\text { Manas et al., } \\
2020\end{array}$ \\
\hline
\end{tabular}

Over the past 10 years, the number of publications on the use of encapsulated microorganisms for the elimination of pollutants in contaminated groundwater has been increasing steadily. The following are among the most commonly used wall/ sphere materials in microencapsulation: carbohydrates (sucrose, starch, maltodextrins, and cyclodextrins), cellulose (carboxymethyl cellulose and its derivatives), gum (Arabic and agar), lipids (wax and fatty acids), and proteins (gelatin, gluten, and casein) [16,21]. Most of these materials have been used in the bioremediation of groundwater in the last decade as listed in Table 1.

Based on Table 1, in the last decade, microencapsulation technology has been widely applied in bioremediation of groundwater polluted by various substances including hydrocarbons, heavy metal, dioxin, herbicides, and plastics. Various micro-carriers grouped as alginates, gums, polymers have also been used as encapsulating materials providing protection as well as nutrition source in suitable environment allowing the release and growth of microbial cells. Interestingly, the microbial cell immobilization could be done by creation of dried cells, which means it does not necessarily need any micro-carrier [8].

Based on this literature review, microencapsulation technologies with various applied micro-carriers as single or combinations keep producing novel micro-engineered materials offering great potential for more innovations in the future. Such innovations are in particular very beneficial for the treatment for contaminated groundwater [22-29].

\section{Conclusion}

There is a need for novel advanced groundwater bioremediation technologies, in particular to ensure a high quality of drinking water and to eliminate water pollutants using suitable treatment systems. Micro-engineered materials produced by microencapsulation technology offer the potential for novel water technologies that can be easily adapted to groundwater bioremediation applications. To date, microencapsulation with various micro-carriers keep producing novel micro-engineered materials offering great potential for more innovations in the coming decades, in particular for treating heavily degradable contaminants in groundwater.

\section{Acknowledgment}

This study is part of work dedicated to Program Hibah Penelitian Terapan (PT) 2020 funded by Kementerian Riset dan Teknologi/ Badan Riset Dan Inovasi Nasional (RISTEK BRIN) or Ministry of Research and Technology of Indonesia.

\section{Conflict of Interest}

No conflict of interest.

\section{References}

1. Bruinsma J (2009) By how much do land, water and crop yields need to increase by 2050? The resource outlook to 2050. Presented at the Food and Agriculture Organization of the United Nations Expert Meeting entitled "How to Feed the World in 2050".

2. (2014) Report, WWD Managing water under uncertainty and risks.

3. Massoud MA, Tarhini A, Nasr JA (2009) Decentralized approaches to wastewater treatment and management: applicability in developing countries J Environ Manage 90(1): 652-659.

4. Mahvi AH, Nouri J, Babaei AA, Nabizadeh R (2005) Agricultural activities impact on groundwater nitrate pollution. International Journal of Environmental Science \& Technology 2(1): 41-47.

5. Saha D, Alam F (2014) Groundwater vulnerability assessment using DRASTIC and Pesticide DRASTIC models in intense agriculture area of the Gangetic plains, India. Environ Monit Assess 186(12): 8741-8763.

6. Coelho LM, Rezende HC, Coelho LM, De Sousa PA, Melo DF, et al. (2015) Bioremediation of polluted waters using microorganisms. Advances in Bioremediation of Wastewater and Polluted Soil 10: 60770.

7. Jyothi NV, Prasanna PM, Sakarkar SN, Prabha KS, Ramaiah PS, et al. (2010) Microencapsulation techniques, factors influencing encapsulation efficiency. J Microencapsul 27(3): 187-197.

8. Saiyari DM, Chuang HP, Senoro DB, Lin TF, Whang LM, et al. (2018) A review in the current developments of genus Dehalococcoides, its consortia and kinetics for bioremediation options of contaminated groundwater. Sustainable Environment Research 28(4): 149-157.

9. Ethica SN, Saptaningtyas R, Muchlissin SI, Sabdono A (2018) The development method of bioremediation of hospital biomedical waste using hydrolytic bacteria. Health and Technology 8(4): 239-254.

10. Tyagi M, da Fonseca MM, de Carvalho CC (2011) Bioaugmentation and biostimulation strategies to improve the effectiveness of bioremediation processes. Biodegradation 22(2): 231-241.

11. Naik MG, Duraphe MD (2012) Review paper on-Parameters affecting bioremediation. International journal of life science and pharma research 2(3): L77-L80.

12. Reis EA, Rocha Leão MH, Leite SG (2013) Slow-release nutrient capsules for microorganism stimulation in oil remediation. Applied biochemistry and biotechnology 169(4): 1241-1249.

13. Ghosh SK (2006) Functional coatings and microencapsulation: a general perspective. Functional coatings, pp. 1-28.

14. Thies C (1996) A survey of microencapsulation processes, Simon Benita, microencapsulation and industrial applications, Ch 1. Maecel Dekker Imp. New York, USA.

15. Bastos DS, Araújo KGL, Rocha Leão MHM (2009) Ascorbic acid retaining using a new calcium alginate-Capsul based edible film. J Microencapsul 26(2): 97-103.

16. Suave J, Dall'agnol EC, Pezzin AP T, Silva DAK, Meier MM, et al. (2006) Microencapsulation: Innovation in different areas. Health and Environment Journal 7(2): 12-20. 
17. Ramírez García R, Gohil N, Singh V (2019) Recent advances, challenges, and opportunities in bioremediation of hazardous materials. In Phytomanagement of Polluted Sites, pp. 517-568.

18. Rathore S, Desai PM, Liew CV, Chan LW, Heng PW (2013) Microencapsulation of microbial cells. Journal of Food Engineering 116(2): 369-381.

19. Nzila A, Razzak SA, Zhu J (2016) Bioaugmentation: An emerging strategy of industrial wastewater treatment for reuse and discharge. Int J Environ Res Public Health 13(9): E846.

20. El Fantroussi S, Agathos SN (2005) Is bioaugmentation a feasible strategy for pollutant removal and site remediation? Curr Opin Microbiol 8(3): 268-275.

21. Dubey R (2009) Microencapsulation technology and applications. Defence Science Journal 59(1): 82-95.

22. Bayat Z, Hassanshahian M, Cappello S (2015) Immobilization of microbes for bioremediation of crude oil polluted environments: a mini review. Open Microbiol J 9: 48-54.

23. Chikhi S, Ferradji FZ, Badis A, Bouzid B (2016) Microbial removal of xylene using free and immobilized Streptomyces sp. AB1: bioreactors application. Desalination and Water Treatment 57(13): 6148-6156.

24. Dellagnezze BM, Vasconcellos SP, Angelim AL, Melo VM, Santisi S, et al.
(2016) Bioaugmentation strategy employing a microbial consortium immobilized in chitosan beads for oil degradation in mesocosm scale. Mar Pollut Bull 107(1): 107-117.

25. Meckenstock RU, Elsner M, Griebler C, Lueders T, Stumpp C, et al. (2015) Biodegradation: updating the concepts of control for microbial cleanup in contaminated aquifers. Environ Sci Technol 49(12): 7073-7081

26. Nutter LA, Strawn IK, White A, Hill C (2019) The Encapsulation of Lactobacillus acidophilus and Lactobacillus casei to Determine Cell Viability in a Hydrogel Biobead Matrix.

27. Rasmussen MT (2018) Co-Encapsulation of Slow Release Substrates and Microbial Cultures in Alginate and Gellan Gum Beads to Promote the Co-metabolic Transformation of 1, 4-Dioxane and Chlorinate Aliphatic Hydrocarbons.

28. Schultz Jensen N, Aamand J, Sørensen SR (2016) Bioaugmentation potential of free and formulated 2, 6-dichlorobenzamide (BAM) degrading Aminobacter sp. MSH1 in soil, sand and water. AMB Express 6(1): 33.

29. Shanbhogue SS, Bezbaruah A, Simsek S, Khan E (2017) Trichloroethene removal by separately encapsulated and co-encapsulated bacterial degraders and nanoscale zero-valent iron. International Biodeterioration \& Biodegradation 125: 269-276. 